\title{
An empirical investigation on factors influencing on brand loyalty
}

\author{
Naser Azad ${ }^{*}$ and Masoud Hassanabadi
}

Department of Management, Islamic Azad University, South Tehran Branch, Tehran, Iran

\begin{tabular}{|c|c|}
\hline C H R O N I C L E & ABSTRACT \\
\hline $\begin{array}{l}\text { Article history: } \\
\text { Received January 12, } 2013 \\
\text { Received in revised format } \\
30 \text { April } 2013 \\
\text { Accepted } 12 \text { May } 2013 \\
\text { Available online } \\
\text { May } 142013 \\
\text { Keywords: } \\
\text { Factor analysis } \\
\text { Brand loyalty } \\
\text { Banking industry }\end{array}$ & $\begin{array}{l}\text { Building a competitive brand is a key success specially in banking industry. This paper presents } \\
\text { a study to investigate important factors influencing brand loyalty among special customers in } \\
\text { one of biggest Iranian banks in Iran. The study designs a questionnaire and distributes it among } \\
249 \text { regular customers who are special customers in various banks in city of Tehran, Iran. } \\
\text { The study uses structural equation modeling to find important factors and they are ranked using } \\
\text { TOPSIS method. In our study, Cronbach alpha has been calculated as } 0.815 \text { and there are eight } \\
\text { influencing factors including flexibility in offering various services, building good relationship } \\
\text { with customers, technology and processes, customers' experiences, brand identity in continuous } \\
\text { advertisement, organization size, customer perception on reputation of brand and customers' } \\
\text { tendency to build better brand loyalty. In our survey, flexibility in offering various services } \\
\text { received the highest rank followed by building good relationship with customers. }\end{array}$ \\
\hline
\end{tabular}

\section{Introduction}

Customer loyalty plays an important role on steady growth of products and services and there are literally various studies on discovering important factors influencing customer loyalty (Jacoby \& Chestnut, 1978; Stern, 1983; Reicbheld \& Sasser, 1990; Oliver, 1999, 2010; Schiffenbauer, 2001; Kotler, 2003; de Chernatony \& Cottam, 2006; Kotler Armstrong, 2009). Aaker (2004) discussed that brand assets are difficult and costly to develop, maintain and adapt. The offering environment is confused, cluttered and complicated in part because of the proliferation of products or services, brand, and sub-brands. According Aaker (2003), when a brand fails to develop or keep differentiation, consumers have no choice for choosing it over others. Aaker (2003) explored various kinds of branded differentiators, the pros and cons of developing them internally versus looking outside for them. Berry (2000) presented a service-branding framework, which underscores the salient effect of customers' service experiences in brand formation. They used four primary strategies that excellent service firms implemented to cultivate brand equity. Branding was not just for tangible goods; it was the success driver for service organizations as well.

*Corresponding author.

E-mail addresses: dr.naserazad@yahoo.com (N. Azad) 
Ehigie (2006) examined how customer expectations, perceived service quality and satisfaction predict loyalty among bank customers in Nigeria. They reported that perception of service quality and satisfaction were substantial predictors of customer loyalty, with customer satisfaction contributing more. De Chernatony and Dall'Olmo Riley (1999) discussed Experts' views about defining services brands and the principles of services branding. Grace and O'Cass (2005) investigated the roles of service brand communications on brand evaluation. The results demonstrated that controlled communications and brand name had a significant impact on customer satisfaction, brand attitudes and brand reuse intentions.

Fornell and Wernerfelt (1987) performed an investigation on defensive marketing strategy by customer complaint management. They showed that defensive marketing could lower the total marketing cost by substantially reducing the expenditure of offensive marketing. Gill et al. (2006) investigated different factors influencing the trust of business clients in their banks. Jones and Farquhar (2007) investigated minor service failures in UK banking and considered the effect that satisfaction with service recovery had on customer intentions to continue their custom and make recommendations, based on as measures of loyalty behaviors. Hankinson and Hankinson (1999) performed an investigation on methods for managing successful brands by performing an empirical study, which compared the corporate cultures of firms managing the world's top 100 brands with those managing outsider brands. Hallowell (1996) performed an empirical study on the relationships of customer satisfaction, customer loyalty, and profitability. Lee and Back (2009) performed an investigation to examine attendees' brand loyalty by understanding the moderator of behavioral brand loyalty.

According to Janiszewski and Van Osselaer (2000), consumers implement brand names and product features to forecast the performance of products. Keller and Aaker (1992) investigated the impacts of sequential introduction of brand extensions. Lambkin and Muzellec (2008) investigated how international banking groups could manage their branding in the context of successive mergers and acquisitions. The study reviewed a number of case histories to demonstrate that banking firms tend to evolve a multi-tiered system for absorbing and rebranding acquisitions. Mitchell and Greatorex (1993) reported in more detail on the differences in perceived risk, its component losses and of the benefits of 14 risk relievers in the buying of six services. The results confirmed the hypothesis that services were riskier than products and that this riskiness was primarily due to extra uncertainty in the purchase of services. Capizzi and Ferguson (2005) outlined the key loyalty-marketing trends for the twenty-first century, which could serve as guideposts as marketers create, expand and revamp their loyalty and customer relationship management (CRM) strategies. Oliver (1980) presented a cognitive model of the antecedents and consequences of satisfaction decisions. Szmigin and Carrigan (2001) discussed about wherefore customer loyalty. Keiningham et al. (2006) examined call center satisfaction in an escalated call center context where callers were organization members of the primary/leveraged brand and had purchased additional co-branded services as part of their membership. Zins (2001) and Zeithaml et al. (2001) performed an investigation on relative attitudes and commitment in customer loyalty models by presenting some experiences in the commercial airline industry.

\section{The proposed study}

This paper presents a study to investigate important factors influencing brand loyalty among special customers in one of biggest Iranian banks in Iran. use the following formula to calculate the minimum number of sample size,

$$
n=\frac{N \times z_{\alpha / 2}^{2} \times p \times q}{\varepsilon^{2} \times(N-1)+z_{\alpha / 2}^{2} \times p \times q},
$$


where $N$ is the population size, $p=1-q$ represents the yes/no categories, $z_{\alpha / 2}$ is CDF of normal distribution and finally $\varepsilon$ is the error term. Since we have $p=0.5, z_{\alpha / 2}=1.96$ and $N=3000$, the number of sample size is calculated as $n=249$. The study designs a questionnaire and distributes it among 249 regular customers who are special customers in various banks in city of Tehran, Iran. The study designs a questionnaire in Likert scale and distributes it among the people who participated in our survey. Cronbach alpha has been calculated as 0.815 and Kaiser-Meyer-Olkin (KMO) Measure of Sampling Adequacy test has been determined as 0.671 . There are 23 questions in our survey and Table 1 summarizes the results rotated principal component analysis.

Table 1

Rotated Component Matrix ${ }^{\mathrm{a}}$

\begin{tabular}{|c|c|c|c|c|c|c|c|c|}
\hline & \multicolumn{8}{|c|}{ Component } \\
\hline & 1 & 2 & 3 & 4 & 5 & 6 & 7 & 8 \\
\hline VAR00001 & .769 & .039 & -.119 & .239 & .149 & -.013 & -.101 & -.039 \\
\hline VAR00002 & .823 & -.036 & .135 & .071 & -.004 & -.039 & -.112 & .128 \\
\hline VAR00003 & .819 & .076 & -.005 & -.115 & .100 & .041 & .137 & .012 \\
\hline VAR00004 & .186 & .133 & .035 & .107 & .747 & .007 & .186 & .033 \\
\hline VAR00005 & .528 & .421 & .205 & -.120 & -.001 & -.022 & .114 & .041 \\
\hline VAR00006 & .087 & .607 & -.061 & .042 & .375 & .238 & .199 & .041 \\
\hline VAR00007 & .005 & .503 & .290 & .126 & .438 & .063 & .054 & -.017 \\
\hline VAR00008 & .101 & .666 & -.097 & .114 & .143 & -.056 & -.211 & .095 \\
\hline VAR00009 & .137 & .450 & .241 & .307 & -.195 & .394 & .103 & .018 \\
\hline VAR00010 & .145 & .221 & .178 & .096 & .572 & .448 & .018 & .096 \\
\hline VAR00011 & -.095 & .165 & -.002 & .112 & .136 & .806 & -.001 & .102 \\
\hline VAR00012 & -.005 & .619 & .217 & -.083 & -.032 & .385 & .169 & -.006 \\
\hline VAR00013 & -.140 & .379 & .553 & .105 & .169 & .167 & -.118 & .081 \\
\hline VAR00014 & .245 & .303 & .418 & .466 & .052 & -.111 & -.272 & .064 \\
\hline VAR00015 & .202 & .277 & -.104 & .205 & -.371 & .090 & .391 & .500 \\
\hline VAR00016 & .069 & .044 & .042 & .054 & .099 & .091 & -.045 & .873 \\
\hline VAR00017 & -.061 & .008 & .034 & .131 & .233 & -.047 & .653 & .344 \\
\hline VAR00018 & .173 & .344 & .132 & .577 & -.145 & -.096 & .176 & .081 \\
\hline VAR00019 & .024 & -.031 & -.035 & .705 & .093 & .349 & .115 & -.112 \\
\hline VAR00020 & .014 & .035 & .264 & .137 & .093 & .111 & .725 & -.267 \\
\hline VAR00021 & .041 & .117 & .768 & -.014 & .089 & -.147 & .224 & -.043 \\
\hline VAR00022 & -.127 & -.058 & .067 & .698 & .315 & .051 & .104 & .257 \\
\hline VAR00023 & .165 & -.244 & .673 & .117 & -.019 & .349 & .149 & .024 \\
\hline
\end{tabular}

As we can observe from the results of Table 1, there are eight factors extracted from factor analysis flexibility in offering various services $\left(\mathrm{X}_{1}\right)$, building good relationship with customers $\left(\mathrm{X}_{2}\right)$, technology and processes $\left(\mathrm{X}_{3}\right)$, customers' experiences $\left(\mathrm{X}_{4}\right)$, brand identity in continuous advertisement $\left(\mathrm{X}_{5}\right)$, organization size $\left(\mathrm{X}_{6}\right)$, customer perception on reputation of brand $\left(\mathrm{X}_{7}\right)$ and customers' tendency to build a trust $\left(\mathrm{X}_{8}\right)$. Fig. 1 demonstrates the effect of each factor.

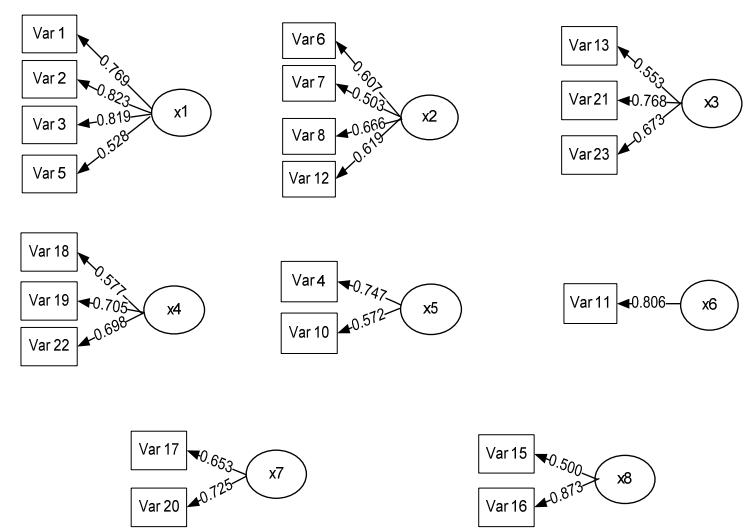

Fig. 1. The results of eight factors 
Fig. 2 demonstrates the initial method to be investigated for the effects of different factors on loyalty.

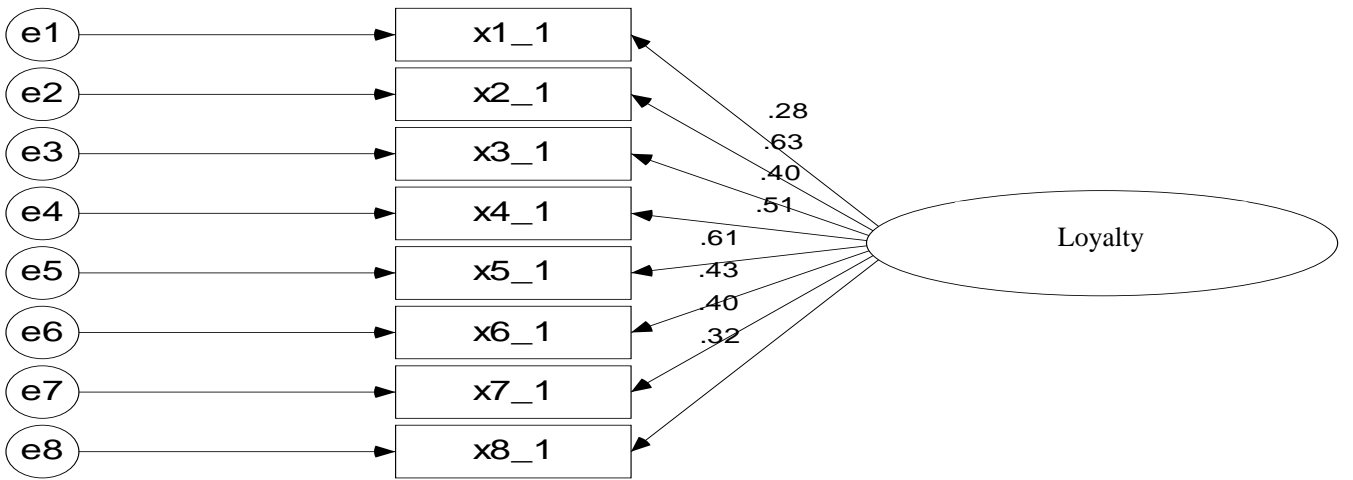

Fig. 2. The results of initial propose model

Table 2 shows the preliminary results of our survey.

\section{Table 2}

The preliminary results of testing different factors on customer loyalty

\begin{tabular}{lcccccccc}
\hline Relationship & Estimated & Standard & Std. error & $\mathrm{T}$ & $\mathrm{P}$-Value & $\mathrm{R}^{2}$ & Result \\
\hline Flexibility in offering various services measures customer loyalty & 1.569 & 0.282 & 0.544 & 2.88 & $\mathrm{P}<0.05$ & 0.08 & Confirm \\
Building good relationship with customers measures customer loyalty & 3.027 & 0.634 & 0.764 & 3.96 & $\mathrm{P}<0.01$ & 0.4 & - \\
Processes measures customer loyalty & 1.508 & 0.403 & 0.436 & 3.46 & $\mathrm{P}<0.01$ & 0.16 & Confirm \\
Experience measures customer loyalty & 2.089 & 0.507 & 0.556 & 3.76 & $\mathrm{P}<0.01$ & 0.26 & Confirm \\
Credibility measures customer loyalty & 1.974 & 0.611 & 0.502 & 3.93 & $\mathrm{P}<0.01$ & 0.37 & Confirm \\
Firm size measures customer loyalty & 1.12 & 0.428 & 0.316 & 3.54 & $\mathrm{P}<0.01$ & 0.18 & Confirm \\
\hline
\end{tabular}

We have used structural equation modeling and Table 3 summarizes the results of our survey.

\section{Table 3}

The summary of statistics on implementation of structural equation modeling

\begin{tabular}{lccc}
\hline Index & Accepted limit & Value & Results \\
\hline Chi-Square/df & $<3$ & 1.65 & Confirmed \\
CMIN & P-value $>0.05$ & 0.034 & Not confirmed \\
RMSEA & $>0.09$ & 0.051 & Confirmed \\
GFI & $>0.90$ & 0.969 & Confirmed \\
AGFI & $>0.085$ & 0.944 & Confirmed \\
GFI & $>0.90$ & 0.936 & Confirmed \\
IFI & $>0.90$ & 0.938 & Confirmed \\
\hline
\end{tabular}

As we can observe from the results of Table 3, except one case, other statistics are significance. We have made some modification on our model and Fig. 3 shows the components of the modified model.

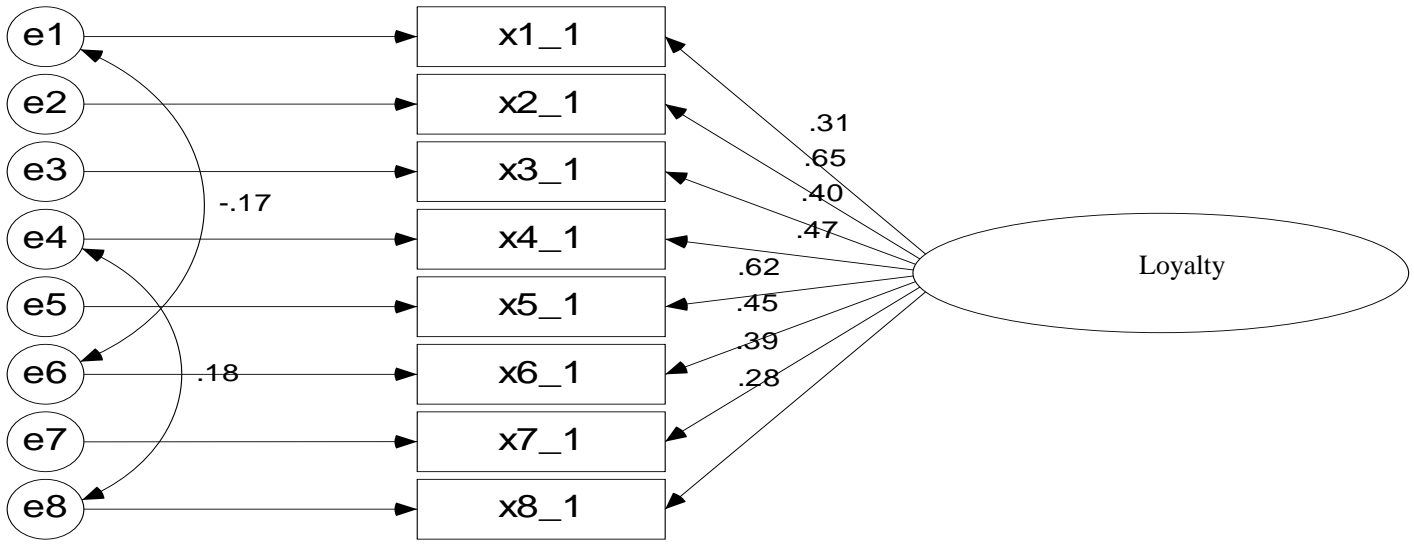

Fig. 3. The modified model

Table 4 demonstrates the results of the implementation of structural equation modeling on modified model as follows, 
Table 4

The preliminary results of testing different factors on customer loyalty

\begin{tabular}{|c|c|c|c|c|c|c|c|}
\hline Variable & Estimated & Standard & Std. error & $\mathrm{T}$ & P-Value & $\mathrm{R}^{2}$ & Result \\
\hline $\mathrm{X}_{1}$ & 2.00 & 0.313 & 0.72 & 2.78 & $\mathrm{P}<0.05$ & 0.08 & Confirmed \\
\hline $\mathrm{X}_{2}$ & 3.55 & 0.649 & 1.026 & 3.46 & $\mathrm{P}<0.01$ & 0.4 & Confirmed \\
\hline $\mathrm{X}_{3}$ & 1.706 & 0.397 & 0.551 & 3.096 & $\mathrm{P}<0.01$ & 0.16 & Confirmed \\
\hline $\mathrm{X}_{4}$ & 2.232 & 0.472 & 0.624 & 3.58 & $\mathrm{P}<0.01$ & 0.26 & Confirmed \\
\hline $\mathrm{X}_{5}$ & 2.287 & 0.617 & 0.665 & 3.44 & $\mathrm{P}<0.01$ & 0.37 & Confirmed \\
\hline $\mathrm{X}_{6}$ & 1.359 & 0.452 & 0.424 & 3.20 & $\mathrm{P}<0.01$ & 0.18 & Confirmed \\
\hline $\mathrm{X}_{7}$ & 1.518 & 0.386 & 0.495 & 3.06 & & & Confirmed \\
\hline $\mathrm{X}_{8}$ & 1.00 & 0.286 & 0.37 & & & & Confirmed \\
\hline
\end{tabular}

In addition, Table 5 presents the summary of some statistical tests on implementation of the structural equation modeling on the second model.

Table 5

The summary of statistics on implementation of structural equation modeling for the second model

\begin{tabular}{lccc}
\hline Index & Accepted limit & Value & Results \\
\hline Chi-Square/df & $<3$ & 1.1 & Confirmed \\
CMIN & P-value $>0.05$ & 0.34 & Confirmed \\
RMSEA & $>0.09$ & 0.02 & Confirmed \\
GFI & $>0.90$ & 0.98 & Confirmed \\
AGFI & $>0.085$ & 0.959 & Confirmed \\
GFI & $>0.90$ & 0.991 & Confirmed \\
IFI & $>0.90$ & 0.991 & Confirmed \\
\hline
\end{tabular}

Based on the results of our survey, we can conclude the final model has confirmed all eight hypotheses of the survey and we can conclude that all eight factors influence brand loyalty, significantly. We have also verified TOPSIS method as multiple criteria decision making method to rank different methods and in our survey, flexibility in offering various services (0.971) received the highest rank followed by building good relationship with customers (0.566) and technology and process (0.559).

\section{The conclusion}

In this paper, we have presented an empirical investigation to study the impact of eight factors on brand loyalty on one of Iranian banks located in city of Tehran, Iran. The study has extracted eight factors based on the implementation of factor analysis and, using structural equation modeling, we have confirmed that all eight factors influenced brand loyalty, significantly. In other words, flexibility in offering various services, building good relationship with customers, technology and processes, customers' experiences, brand identity in continuous advertisement, organization size, customer perception on reputation of brand and customers' tendency help us build a brand loyalty with customers.

\section{References}

Aaker, D. A. (2003). The power of the branded differentiator. MIT Sloan Management Review, 45(1), 83-87.

Aaker, D. A. (2004). Leveraging the corporate brand. California Management Review, 46(3), 6-18.

Berry, L. L. (2000). Cultivating service brand equity. Journal of the Academy of Marketing Science, 28(1), 128-137.

Capizzi, M. T., \& Ferguson, R. (2005). Loyalty trends for the twenty-first century. Journal of Consumer Marketing, 22(2), 72-80. 
de Chernatony, L., \& Cottam, S. (2006). Why are all financial services brands not great?. Journal of Product \& Brand Management, 15(2), 88-97.

De Chernatony, L., \& Dall'Olmo Riley, F. (1999). Experts' views about defining services brands and the principles of services branding. Journal of Business Research, 46(2), 181-192.

Ehigie, B. O. (2006). Correlates of customer loyalty to their bank: a case study in Nigeria. International Journal of Bank Marketing, 24(7), 494-508.

Fornell, C., \& Wernerfelt, B. (1987). Defensive marketing strategy by customer complaint management: a theoretical analysis. Journal of Marketing research, 337-346.

Gill, A. S., Flaschner, A. B., \& Shachar, M. (2006). Factors that affect the trust of business clients in their banks. International Journal of Bank Marketing,24(6), 384-405.

Grace, D., \& O'Cass, A. (2005). Examining the effects of service brand communications on brand evaluation. Journal of Product \& Brand Management,14(2), 106-116.

Hallowell, R. (1996). The relationships of customer satisfaction, customer loyalty, and profitability: an empirical study. International Journal of Service Industry Management, 7(4), 27-42.

Hankinson, P., \& Hankinson, G. (1999). Managing successful brands: An empirical study which compares the corporate cultures of companies managing the world's top 100 brands with those managing outsider brands. Journal of Marketing Management, 15(1-3), 135-155.

Janiszewski, C., \& Van Osselaer, S. M. (2000). A connectionist model of brand-quality associations. Journal of Marketing Research, 37(3), 331-350.

Jacoby, J., \& Chestnut, R. W. (1978). Brand loyalty: Measurement and management (p. 157). New York: Wiley.

Jones, H., \& Farquhar, J. D. (2007). Putting it right: service failure and customer loyalty in UK banks. International Journal of Bank Marketing, 25(3), 161-172.

Keiningham, T. L., Aksoy, L., Andreassen, T. W., Cooil, B., \& Wahren, B. J. (2006). Call center satisfaction and customer retention in a co-branded service context. Managing Service Quality, 16(3), 269-289.

Keller, K. L., \& Aaker, D. A. (1992). The effects of sequential introduction of brand extensions. Journal of marketing research, 35-50.

Kotler, P. (2003). Marketing insights from A to Z: 80 concepts every manager needs to know. Wiley.

Kotler, P., \& Armstrong, G. (2009). Principles of marketing. Pearson Education.

Lambkin, M., \& Muzellec, L. (2008). Rebranding in the banking industry following mergers and acquisitions. International Journal of Bank Marketing,26(5), 328-352.

Lee, J. S., \& Back, K. J. (2009). An examination of attendee brand loyalty: Understanding the moderator of behavioral brand loyalty. Journal of Hospitality \& Tourism Research, 33(1), 30-50.

Mitchell, V. W., \& Greatorex, M. (1993). Risk perception and reduction in the purchase of consumer services. Service Industries Journal, 13(4), 179-200.

Oliver, R. L. (1980). A cognitive model of the antecedents and consequences of satisfaction decisions. Journal of marketing research, 17(4), 460-469.

Oliver, R. L. (1999). Whence consumer loyalty?. the Journal of Marketing, 33-44.

Oliver, R. L. (2010). Satisfaction: A behavioral perspective on the consumer. ME Sharpe Incorporated.

Reicbheld, F. P., \& Sasser, W. E. (1990). 7ero Defeciions: Quolify Comes to Services. Harvard business review.

Schiffenbauer, A. (2001). Study all of a brand's constituencies. Marketing News, 35(11), 17.

Stern, W. (1983). A good name could mean a brand of fame. Advertising Age,17, M53-M54.

Szmigin, I., \& Carrigan, M. (2001). Wherefore customer loyalty. Journal of Financial Services Marketing, 6(1), 6-8.

Zeithaml, V. A., Rust, R. T., \& Lemon, K. N. (2001). The customer pyramid: creating and serving profitable customers. California Management Review,43(4), 118-142.

Zins, A. H. (2001). Relative attitudes and commitment in customer loyalty models: some experiences in the commercial airline industry. International Journal of Service Industry Management, 12(3), 269-294. 